\title{
Female religious leadership in Switzerland: norms, power, and money
}

\section{Jörg Stolz \& Christophe Monnot}

To cite this article: Jörg Stolz \& Christophe Monnot (2019) Female religious leadership in Switzerland: norms, power, and money, Journal of Contemporary Religion, 34:2, 353-373, DOI: 10.1080/13537903.2019.1621552

To link to this article: https://doi.org/10.1080/13537903.2019.1621552

曲 Published online: 08 Jul 2019.

Submit your article to this journal

Џ Article views: 4

View Crossmark data $₫$ 


\title{
Female religious leadership in Switzerland: norms, power, and money
}

\author{
Jörg Stolz and Christophe Monnot
}

\begin{abstract}
Women's access to positions of leadership in religions is a highly contested issue in Western societies, both inside religions themselves and in societal discussions of religion. Reliable data on actual female leadership are, however, scarce, especially in European countries and regarding minority religions. This article describes and explains statistically the normative openness of congregations to female leadership as well as the actual existence, position, and financial remuneration of female leaders across the whole range of religious traditions in Switzerland. The study is based on data from the representative National Congregations Study of 2008/2009. Our results show that, despite considerable normative openness, female spiritual and administrative leadership remains scarce in most religious traditions. The highest percentage of female spiritual leaders can be found in the milieu of alternative spirituality, followed by the Reformed congregations. A generally high percentage of female leadership can be found on administrative boards. It is only leadership positions in certain Christian traditions (Reformed, Catholic, Evangelical-classical) that are normally remunerated for women; many other traditions do not have female leadership or, as in the case of the milieu of alternative spirituality, such leadership positions are not remunerated.
\end{abstract}

\section{ARTICLE HISTORY}

Received 13 September 2016

Accepted 22 July 2018

\section{KEYWORDS}

Female leadership; religions; religious organisation; congregations; women; Switzerland

\section{Introduction}

Women's access to positions of leadership in religions is a highly contested issue in Western societies, both inside religions themselves and in societal discussions of religion (de Gasquet 2009; Chaves 1997; Willaime 1996). Such discussions concern, for example, the question whether the Catholic Church should allow women to be ordained, whether fundamentalist churches can accept female pastors or elders, and whether there should be female rabbis and imams in Judaism and Islam, respectively. Ironically, while women constitute the majority of practising members in most religions in Europe, this normally does not translate into power and religious leadership (Walter and Davie 1998, 640). What Grace Davie $(1994,4)$ notes for Christians-namely, that "women are under-represented behind the pulpit, but over-represented in the 
Church pews"-is true mutatis mutandis for the religious field in Western societies in general.

There is an important body of literature that describes the difficulty that women often have in accessing positions of administrative and spiritual leadership in the religious field. For example, there are excellent historical, quantitative, and comparative analyses of this issue as well as case studies, especially in the US, which deal with both majority and minority as well as both autochthonous and non-autochthonous religions (Adams 2007; Konieczny and Chaves 2000; Purvis 1995; Sullins 2000; Chaves 1997). However, there seem to be two things missing: a lack of quantitative studies of female leadership in European countries (but see Niemelä 2011) and a lack of studies that deal statistically with majority and minority religions in one and the same framework.

Our contribution seeks to address these two deficits. We describe and explain statistically the access that women have to administrative and spiritual positions of leadership in a European country-namely, Switzerland - and we do this for religions across the whole religious field, including majority and minority as well as autochthonous and non-autochthonous religions.

The three key questions of our article are: (1) how do congregations belonging to different religious traditions in Switzerland differ concerning their norms which regulate women's access to leadership positions? (2) What leadership positions do women actually hold in these religious groups and what attributes do these positions have? Specifically, are these positions financially remunerated? (3) What social and theological factors determine both the norms governing women's access to leadership positions and the actual extent of female leadership in congregations?

A congregation, for the purpose of this article, is a 'local religious group'. We define the term following Mark Chaves (2004, 1-2), as

a social institution in which individuals who are not all religious specialists gather in physical proximity to one another, frequently and at regularly scheduled intervals, for activities and events with explicitly religious content and purpose, and in which there is continuity over time in the individuals who gather, the location of the gathering, and the nature of the activities and events at each gathering. ${ }^{1}$

This definition may be applied to local groups of any religious tradition and covers groups historically established in Europe as well as those in the process of becoming established

A leadership position in a congregation is a status role giving the incumbent a certain amount of formal authority over some or all members. It may be of an administrative (e.g. membership of a board, administrator) or spiritual (e.g. pastor, priest, rabbi, imam, prophet, guru) 
type. A leadership position may be occupied full- or part-time and may or may not be financially remunerated.

The data presented originate from a national congregation study conducted in Switzerland in 2008/2009 (Stolz et al. 2011). This was the first European survey to use the well-known methodology employed in the national congregations studies in the US (Chaves 2004). Because of its specific strategy of sampling and weighting, the Swiss National Congregations Study is able, unlike its US model, to compare religious traditions across the entire field of religions.

The contribution of this article is to describe and explain aspects of female leadership-norms governing access, actual power, and financial remuneration-across the entire religious field in Switzerland. We want to be clear from the outset that the word 'explain' is used here not in an historical, but in a statistical sense, as our aim is to account for a certain amount of variance in our dependent variables.

The structure of this article is as follows. We describe a number of theoretical ideas about mechanisms leading to or preventing female leadership in religious groups, before describing the Swiss context. We then outline our method and present our results regarding norms governing access, actual power, and financial remuneration.

\section{Women's access to leadership positions in religious congregations}

An increasing number of women are beginning to occupy religious leadership positions in Western societies. This influx has been relatively slow (certainly slower than in other domains of society); it has involved important struggles and negotiations; it is the result of not only changes within religious organisations themselves, but also important external pressures exerted by, for example, the state, the women's movement, and civil society in general (Chaves 1997, 38-40). In this article, we do not deal with women's slow but steady march to power in religious organisations diachronically; we deal with the state of power distribution and its organisational and ideological determinants synchronically. Previous research has shown at least six points that are important for our research.

Firstly, female leadership depends in important ways on religious traditions and sub-traditions. Religious traditions may both prescribe certain rules concerning female leadership and provide the theological legitimation for such rules and practices. These rules and legitimations are not necessarily stable, thus may change over time. We do not have space here to provide even a cursory description of the positions of female leadership in the different religions; therefore, we only note some points that will be important for the interpretation of our results. Roman Catholics do not allow women to be ordained, but, in cases where no male priest is available, non-ordained pastoral 
assistants (many of whom are women) may lead the congregation. The Reformed churches in Switzerland have allowed women to be ordained since 1963 (Kunz and Giselbrecht-Häfner 2014) and women have held some of the most powerful positions in Reformed churches (e.g. as presidents of the cantonal churches). Evangelicals are very diverse concerning their norms which govern women's access to spiritual power. Evangelical-conservative (fundamentalist) groups are strict in excluding female pastors, legitimating this practice by pointing to Bible verses such as 1 Corinthians 14:34: "The women are to keep silent in the churches, for they are not permitted to speak" (Adams 2007, 82; Riesebrodt and Chong 1999, 64). In contrast, charismatic and traditional Evangelicals may allow female pastors at least in principle, but are in fact often very traditional in terms of their mind-set (Gill and Oleson 2013, 285). The Salvation Army is an exception in this respect in that it gave women spiritual power as early as the end of the nineteenth century. Haredi and Orthodox Jews do not normally allow female rabbis, but reformed and conservative congregations may do so (de Gasquet 2009, 221; Marx 2013, 228). ${ }^{2}$ In Islam, the overwhelming majority of Muslim groups believe that only a man can perform the role of imam (prayer leader). The progressive women who have recently become female imams have provoked immense anger and criticism in much of the Islamic world (Sharify-Funk and Haddad 2012, 50). In Buddhism, it is understood that both women and men can learn to provide Buddhist teachings. However, different schools and groups think about gender and leadership in different ways. In the Theravada groups studied by Wendy Cadge (2004) in the US, for example, the non-autochthonous group thought that only men could teach Buddhism, while the autochthonous group believed that both female and male leadership was possible. In most Hindu temples, it is quite naturally assumed that priests have to be men; on the other hand, there are female priests in temples worshipping Adi Parashakti and a number of well-known female gurus (Rageth 2014). In neo-Hindu groups that practise Yoga, female leadership is completely accepted and very common (Baumann $2007,230)$. In the milieu of alternative spirituality, there are very open views on women's access to spiritual authority (Höllinger and Tripold 2012, 106-108; Wessinger 1993, 1-4). The milieu of alternative spirituality can be defined as a large group of people who are interested in body-mind practices (e.g. Zen meditation, Yoga, Alexander technique), psychotherapy, complementary medicine, and new religious movements and who interpret these practices and beliefs in a more or less spiritual way (Höllinger and Tripold 2012, 12). Alternative spirituality is deeply intertwined with female emancipation and many alternative spirituality groups are "run largely for women by women, and deal directly with the difficulties of the contemporary feminine condition" (Woodhead 2008, 193).

Secondly, as some of the above examples indicate, women's increased access to leadership positions is more likely in religious sub-traditions 
that are theologically and politically liberal or progressive and less likely in sub-traditions that are conservative or fundamentalist. Chaves (1997, 14) points out that women's ordination in the US was possible in the liberal wing, but difficult in the conservative wing of different denominations. According to Chaves, the issue of women's access to leadership positions has been, since the first half of the twentieth century, a marker of loyalty and affiliation to either of these two wings. Jean-Paul Willaime (1996) has traced the impact of liberal theology in France during the twentieth century, first on the training of women in academic theology, then on employing women as ministry assistants, and finally on women's ordination as full pastors. In our study, we are able to measure where congregations position themselves politically and theologically on a liberal-conservative scale, in order to assess possible correlations with actual and normative openness to female leadership.

Thirdly, there is not necessarily a strong correlation between the norms governing women's access to leadership positions and the actual power that women have in a religious group. Chaves $(1997,5)$ has called this phenomenon "loose coupling". Thus, the introduction of female ordination as a legal possibility in many mainline Protestant denominations has not automatically led to the actual ordination of many female pastors. Neither has the proscription of female ordination in Catholic parishes prevented women from filling many positions that, according to the rules, should only be filled by men. This does not mean that formal rules do not influence the likelihood of female leadership in religious congregations, but there are many other factors (e.g. availability of male and female candidates, preferences and power structures in the local congregation, extent of outside pressure) that play an equally important role. For our study, this insight leads us to measure norms governing female leadership and actual female leadership (power) separately and to establish empirically whether there is a correlation. We are thus interested in gauging the extent to which religious traditions, given their different norms and legitimations, determine the actual existence of female leadership in different congregations.

Fourthly, female leadership is linked to the question whether the congregations in question are mainly autochthonous or non-autochthonous (Ebaugh and Chafetz 1999, 600; Min 2008, 235). Many immigrants in Western societies come from societies with more traditional gender roles. It is therefore likely that their congregations will reflect this more traditional outlook in terms of both norms governing women's access to leadership positions and actual leadership by women. Furthermore, it has been argued that men in congregations with a high proportion of immigrants may be especially keen to fill positions of authority since they may have lost their 
occupational status in the immigration process (Ebaugh and Chafetz 1999, 601).

Fifthly, norms governing female leadership and positions may be influenced by the social composition of the congregation. We may hypothesise that a group with a higher percentage of female members will ceteris paribus be more likely to have a female leader than a group with a lower percentage of female members. This could be because female leadership may seem more acceptable or because female leaders may be found more easily in a group with a higher number of female members. It may also be that a higher percentage of younger and more highly educated members, which indicates a more modern outlook on life, may facilitate the employment of female spiritual leaders.

Finally, norms governing female leadership and positions may be linked to the attributes of a congregation, for example, its urban or rural location, its size and resources, and when it was founded. The urban-rural link is theoretically complex. Congregations in rural areas may be more likely to have female spiritual leaders if the more unattractive rural positions are given predominantly to women. Conversely, congregations in urban areas may also be more likely to have female spiritual leaders if urban contexts with their more modern lifestyle make employing female spiritual leaders less difficult. The literature otherwise suggests that female spiritual leaders are more often found in smaller congregations and in congregations with fewer resources, because women are employed more easily in positions with less prestige (Konieczny and Chaves 2000, 261; Marx 2013, 233). When the congregation was founded may again have a complex effect on female leadership. If a congregation is new, it is likely to absorb the ideas of female emancipation from its societal surroundings and thus be more open to female leadership. However, if a non-autochthonous religion founds a new congregation in a Western country, this may mean that it does not have much time to adapt to more liberal positions and may therefore have a relatively conservative attitude to female leadership (Ebaugh and Chafetz 1999, 601).

\section{The Swiss context}

As we do not have space to describe the Swiss context extensively, we limit ourselves to a small number of central elements. Like most other Western countries, Switzerland has undergone an impressive phase of female emancipation in recent decades, including more egalitarian laws, norms, and gender roles. Women have gained access to leadership positions in virtually all domains of society, the most striking of which occurred in 2010/2011 when women gained a majority in the Federal Council (four out of seven members). Female emancipation has led to a general pressure on religious groups to open up their leadership positions to women and the 
general population is fiercely critical of religious groups that do not guarantee equal rights to women (Stolz et al. 2016, 139-141).

Until the 1950s, Switzerland was an almost completely Christian country, with roughly $60 \%$ of the population Reformed and $40 \%$ Roman Catholic. Since the 1960s, there has been an increasing number of individuals with no religion $(20.1 \%$ in 2010$)$ and growing religious diversity. The new religious diversity has been caused, on the one hand, by the immigration of individuals with Muslim, Hindu, Buddhist, Orthodox or other religious backgrounds and, on the other hand, by the emergence of new alternative spirituality groups that form what has been called the "alternative spirituality milieu" (Stolz et al. 2016, 57-59; Heelas et al. 2005). ${ }^{3}$ These changes are important for our investigation of female leadership in religions, since non-autochthonous groups often import rather conservative positions concerning female leadership, while alternative spirituality groups tend to hold progressive positions in this respect.

In most Swiss cantons, some religious groups are 'established' (officially recognized as having a public function), while others are not (Pahud de Mortanges 2007; Stolz and Chaves 2017, 15). The established groups (in most cantons, the Reformed and Roman Catholic churches) are organised in accordance with public law and have both special privileges and special obligations. Among the privileges are (in most cantons) the right to levy a church tax, while an important obligation is that they have to operate democratically and to be monitored (to a certain degree) by the State. The latter leads to the fact that established churches tend to feel additional pressure to align themselves with principles of gender equality.

Finally, in Switzerland, as in other Western European countries, women are generally more religious than men (Houtman and Aupers 2006, 99; Voas, McAndrew, and Storm 2013, 260; Woodhead 2008, 190; Stolz et al. 2016, 156). Data for Switzerland from 2014 at the individual level show a significantly higher level of religious belief, prayer, and churchgoing for women than for men. This is true for Christian religiosity, alternative spirituality, and people without any religious belonging (Flaugergues 2016, 9-20). Our own National Congregations Study data show that attendance at religious rituals is more prevalent among women than men in all religious traditions, except Judaism and Islam where attendance norms are gendered (attendance at the synagogue or mosque may be prescribed for men, but not for women) (Stolz et al. 2011, 25). This is important because it makes the point that most people practising religion in Switzerland are women, but most people leading religion are men.

\section{Method and data}

The data in this section stem from a quantitative survey conducted in the winter of 2008/2009 as part of the National Research Programme 58 of the 
Swiss National Science Foundation (SNF) (Stolz et al. 2011; Monnot 2013). ${ }^{4}$ The survey followed the model of the National Congregations Study survey conducted in the US (Chaves 2004).

\section{Census of congregations and sampling}

In order to create the sampling frame, we conducted a census of all local religious groups in Switzerland between September 2007 and September 2008. ${ }^{5}$ This combined all the available sources of information, including lists of local religious groups produced by churches and religious federations, lists (whether published or not) compiled by scholars, lists on institutional web sites, directories or databases as well as interviews with informed individuals within the religious milieus. All this information was analysed to identify local religious congregations. A congregation was only retained on the final list if it appeared in two independent sources of information. From the resulting list of 5,734 congregations relating to all religions in Switzerland, we then chose a random sample of 1,040 religious congregations, stratified to over-represent religious minorities.

\section{Data collection}

Computer-assisted telephone interviews (CATI) were conducted in the three national languages (German, French, Italian) with one key informant for every congregation in the sample (in most cases, the spiritual leader); the interviews followed a standardised questionnaire of 250 questions focusing on observable practices and facts. The different religious federations supported the project by encouraging the local leaders to take part in the survey, resulting in a response rate of 71.8\% (Monnot 2013, 244-255). Survey data, questionnaire, and variable coding are available on the Data and Research Information Service (DARIS) database (see https://forsbase.unil.ch/project/study-public-overview/15332/0/).

\section{Dependent variables}

Normative openness to female leadership (access norms) was measured with five dichotomous items which asked whether the congregation allowed women, if otherwise qualified, to (1) serve as fully fledged members of governing bodies or co-ordinating committees (yes/no), (2) be head clergyperson or primary religious leader (yes/no), (3) preach at a main worship service (yes/no), (4) teach by themselves a class that included adult men (yes/no), and (5) hold all the voluntary leadership positions that men can hold (yes/no). These items were combined by simple addition into a scale measuring normative openness to female leadership, ranging from 0 (very closed) to 5 (very open). Cronbach's Alpha was .679. 
The existence of a full- or part-time and a paid or voluntary female spiritual leader in the congregation was measured with the following question: is there one person who is the spiritual leader of your congregation-a priest, senior pastor, spiritual guide, etc.? (Yes/no) If this question was answered with 'yes', three additional questions were asked: (1) is this person male or female? (male/female); (2) is this person paid or a volunteer? (paid/volunteer); (3) does this person work full-time in the congregation? (Yes/no).

The existence of a council or board of management and the percentage of women/men on it were measured with the following three questions: (1) is your congregation managed by a council or a board of management that is responsible for strategies and objectives within the congregation? (yes/no); (2) how many people sit on this council/board?; (3) how many of these are women?

\section{Independent variables}

In order to capture religious traditions (and sub-traditions), we used a twelve-step variable distinguishing Roman Catholic, Reformed, Evangelical-classical, Evangelical-charismatic, Evangelical-conservative, Orthodox, Other Christian, Jewish, Muslim, Buddhist/Hindu non-autochthonous temple, (neo-)Buddhist/Hindu alternative spirituality groups, and other alternative spirituality groups. This classification is not balanced as it does not use the same level of sub-classification for all religions. The reason for this is the actual distribution of groups, with some traditions having only very few congregations. Evangelicals are distinguished according to theological criteria, with neo-Pietistic groups (mostly founded in the nineteenth century) called 'Evangelical-classical', fundamentalist-literalist groups called 'Evangelical-conservative', and Pentecostal and charismatic groups called 'Evangelical-charismatic'. This classification does not separate Buddhists from Hindus, but distinguishes between Buddhist/Hindu non-autochthonous temples, on the one hand, and general Buddhist/Hindu alternative spirituality groups, on the other hand. The former are mainly congregations comprising immigrants, while the latter are mainly autochthonous groups that are strongly grounded in Buddhist and Hindu traditions but at the same time part of the 'alternative spirituality milieu' (Monnot and Stolz 2014, 85).

Conservative/liberal theology and political ideology were measured with two three-step questions that were worded as follows: (1) on a political level, would your congregation be considered to be on the left, on the right or in the centre? (2) On a theological level, would your congregation be considered progressive, conservative or in the centre?

A number of questions measured the social composition of the congregation. The key informant was asked to indicate, with regard to 
those participating regularly in the activities of the congregation: (1) the percentage of women; (2) the percentage of people aged over 60; (3) the percentage of people aged $18-35$; (4) the percentage of people with university education; (5) the percentage of people with an annual income of under CHF25,000; (6) the percentage of people with an annual income of over CHF100,000.

Three questions measured relevant attributes of the congregation. Whether the congregation had one of the national languages as their main language for rituals was used as a proxy for autochthonous $v s$. non-autochthonous congregation. The size of the political community in which the congregation was located was measured with an eight-step variable, with responses ranging from 1 ( $<1,000$ inhabitants) to 8 (100,000 inhabitants and more). This variable also captures the difference between congregations situated in urban or rural contexts. Finally, we asked when the congregation had been founded.

\section{Data analysis}

We used nested linear regression models for the dependent variable 'normative openness to female leadership' and nested logistic regression models for the dependent variable 'existence of a female leader'. In the multivariate regression models, the variables of religious tradition were entered as dummy variables (with 'Catholic' functioning as the reference category). Data were not weighted. We conducted extensive residual analyses to detect possible misspecifications in our models.

\section{Results}

\section{Norms: rules permitting or proscribing female leadership}

Our data permit us to make a number of interesting generalisations about norms regulating women's access to positions of leadership in different religions (Table 1). Comparing the norms governing access to different positions, we see that high-status positions and those involving spiritual leadership are more closed to women than low-status and administrative positions. This seems to be true in all religious traditions. It is, in other words, easier for a woman to become a general voluntary leader or a member of a governing board than to become a preacher at a main worship service or the head clergyperson. For example, 97.3\% of Catholic groups and $45.5 \%$ of Evangelical-conservative groups stated that women may hold all voluntary leadership positions that men can hold, but only $9.8 \%$ of Catholic groups and $4.5 \%$ of Evangelical-conservative groups stated that the head clergyperson or primary religious leader may be female. The most open traditions regarding norms permitting a woman to be the main spiritual 


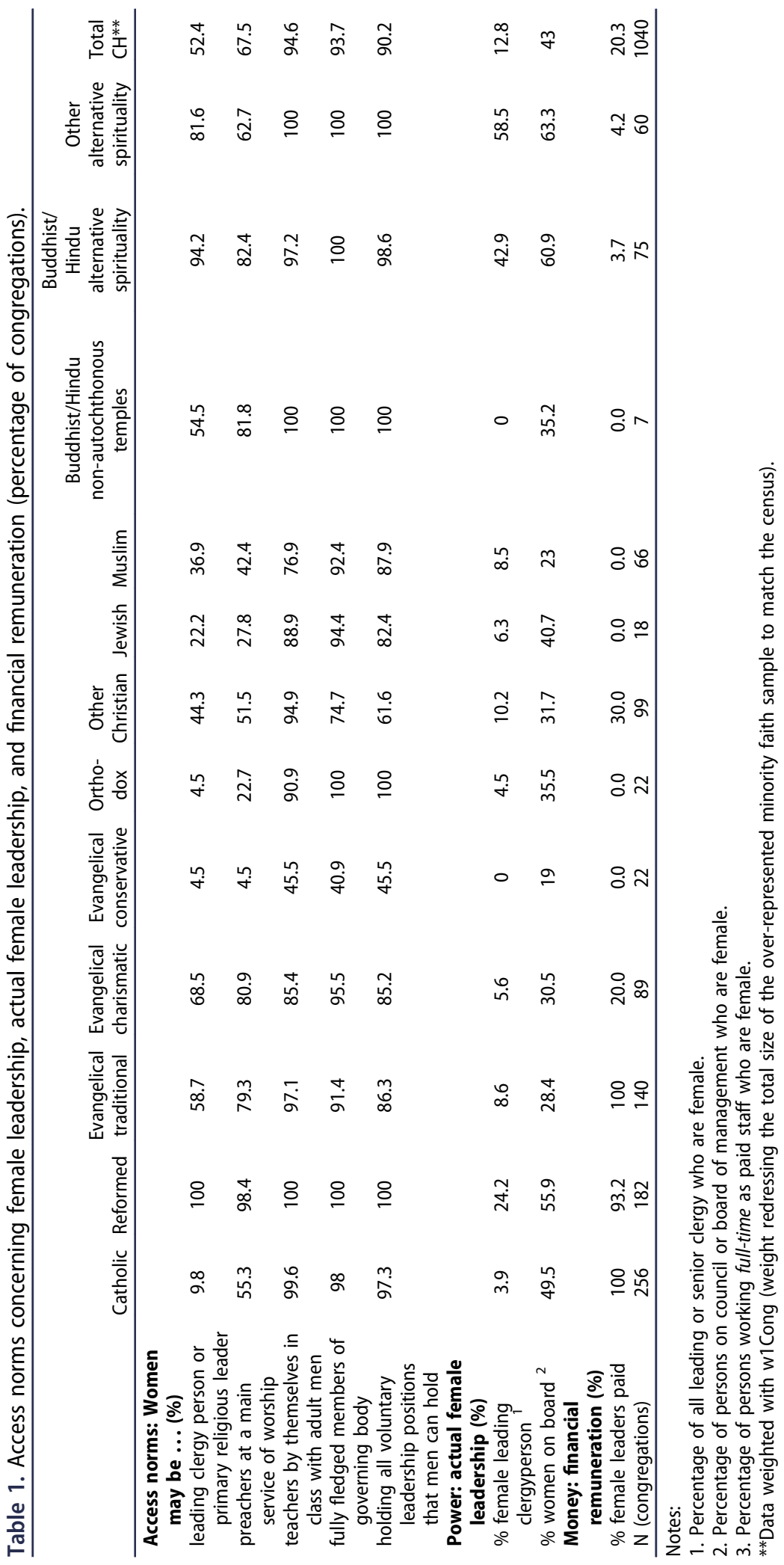


leader are Reformed (100\%), Buddhist/Hindu alternative spirituality groups (94.2\%), other alternative spirituality groups (81.6\%), Evangelical-charismatic groups (68.5\%), and Evangelical-classical groups (58.7\%).

It is interesting to note that it is not only Muslims who are rather conservative regarding norms governing women's access to leadership positions. This is important, since it is often Muslims who are accused in public discourse of holding 'backward opinions' on the place of women, a notion that is used to claim that integrating Muslims into Western societies is impossible (Stolz et al. 2016, 141-142). Our data, however, show that the norms concerning female leadership are just as, if not more, conservative among Evangelical-conservative and Orthodox congregations as they are among Muslims. Readers might wonder how it is possible that $36.9 \%$ of Muslim groups stated that their head clergyperson may be a woman. The answer is that these are actually either groups of Muslim women that organise prayers or Sufis. In mainstream Muslim groups, there can be no such thing as a female imam.

A multivariate perspective shows that the bivariate differences between different religious traditions and sub-traditions hold when we control for other variables (Table 2). In fact, religious tradition is by far the most important predictor of access norms (explaining 30.6\% of the variance). We also found that theologically and politically conservative congregations are less open to female leadership than progressive congregations. Theological conservatism is empirically more important than political conservatism. Furthermore, we see that social composition and other attributes of the congregation also have some significant effects. Congregations with higher percentages of younger and more educated people-and, interestingly, poorer people-are more likely to be more open to female leadership. We cannot completely explain why congregations with higher percentages of poor participants should be more open to female leadership. Some of the effect stems from the fact that some conservative groups-especially conservative Evangelicals-are both closed to female leadership and have a very low percentage of poor participants. However, the effect remains significant even when we control for religious tradition. Also, congregations that have been founded more recently have access norms that are slightly more open. Controlling for size of congregation, language region, and religious regulation of the canton did not change the results, which is why we did not include these variables in the models.

\section{Power: actual female leadership}

Our results on power-actual female leadership-mirror to a certain extent the findings that we presented in the previous section on norms: women can obtain different positions with varying degrees of difficulty. Women are much more often on administrative boards than they are the main 
Table 2. Linear regression of normative openness to women and logistic regression of actual female leadership.

\begin{tabular}{|c|c|c|c|c|c|}
\hline & \multicolumn{2}{|c|}{$\begin{array}{c}\text { linear regression } \\
\text { normative openness to } \\
\text { women }\end{array}$} & \multicolumn{3}{|c|}{$\begin{array}{l}\text { logistic regression } \\
\text { actual female leadership }\end{array}$} \\
\hline & Model 1 & Model 2 & Model 1 & Model 2 & Model 3 \\
\hline & beta & beta & $\operatorname{Exp}(B)$ & $\operatorname{Exp}(B)$ & $\operatorname{Exp}(B)$ \\
\hline Roman Catholic (reference) &.-- &.-- &.$-^{-}$ &.-- & -.- \\
\hline Reformed & $.421^{* *}$ & $.366^{* *}$ & $7.65216^{* *}$ & $7.233^{* *}$ & $3.501^{* *}$ \\
\hline Evangelical-classical & $.143^{* *}$ & $.246^{* *}$ & 2.323 & .101 & .110 \\
\hline Evangelical-charismatic & $.127^{* *}$ & $.246^{* *}$ & 1.157 & 1.526 & .745 \\
\hline Evangelical-conservative & $-.248^{* *}$ & $-.173^{* *}$ & 0.0 & 0.0 & 0.0 \\
\hline Orthodox & -.046 & .019 & 1.143 & 1.079 & 1.130 \\
\hline Other Christian & $-.074^{*}$ & -.038 & 2.182 & .066 & .286 \\
\hline Jewish & -.047 & -.021 & 1.714 & 1.932 & 1.646 \\
\hline Muslim & $-.063^{*}$ & .046 & 2.353 & 3.063 & 2.509 \\
\hline Buddhist/Hindu non-autochthonous temples & $.063^{*}$ & $.094^{* *}$ & 0.0 & 0.0 & 0.0 \\
\hline Buddhist/Hindu alternative spirituality & $.206^{* *}$ & $.229^{* *}$ & $18.182^{* *}$ & $14.214^{* *}$ & $6.791^{* *}$ \\
\hline Other alternative spirituality & $.107^{* *}$ & $.129^{* *}$ & $30.857^{* *}$ & $24.224^{* *}$ & $16.051^{* *}$ \\
\hline Politically left & & $.104^{* *}$ & & 1.140 & .895 \\
\hline Politically centre & & $.082^{* *}$ & & .845 & .754 \\
\hline Politically right (reference) & &.-- & &.- &.-- \\
\hline Theologically liberal & & $.226^{* *}$ & & $2.096^{* *}$ & 1.729 \\
\hline Theologically centre & & $.212^{* *}$ & & $1.722^{*}$ & 1.433 \\
\hline Theologically conservative (reference) & & -- & & -- &.-- \\
\hline$\%$ members female & & .054 & & $1.020^{*}$ & $1.020^{*}$ \\
\hline$\%$ members aged $>60$ & & -.036 & & 1.005 & 1.005 \\
\hline$\%$ members aged $18-35$ & & $-.065^{*}$ & & 1.000 & 1.001 \\
\hline$\%$ members university education & & $.117^{* *}$ & & $1.012^{*}$ & $1.012^{*}$ \\
\hline$\%$ members annual income $<25,000$ & & $.069^{* *}$ & & 1.007 & .975 \\
\hline$\%$ members annual income $>100,000$ & & .013 & & .901 & .894 \\
\hline Congregation non-national language & & -.053 & & .979 & 1.047 \\
\hline Congregation founding date & & $-.107^{* *}$ & & 1.044 & 1.059 \\
\hline Size of political community & & .002 & & .929 & .922 \\
\hline$\%$ members female *Evangelical-classical & & & & 1.062 & 1.050 \\
\hline$\%$ members female ${ }^{*}$ Other Christian & & & & 1.058 & 1.029 \\
\hline Normative openness to women & & & & & $23.379 * *$ \\
\hline Constant & & & $0.42^{* *}$ & $.006^{* *}$ & $.001^{* *}$ \\
\hline Hosmer Lemeshow Fit & & & 1.0 & .456 & .179 \\
\hline Durbin Watson & 1.715 & 1.715 & & & \\
\hline R2 (Adj./Cox \& Snell) ${ }^{(1)}$ & $30.6 \%$ & $39.3 \%$ & $12.5 \%$ & $15.5 \%$ & $16.9 \%$ \\
\hline $\mathrm{N}$ & 1007 & 1007 & 965 & 965 & 965 \\
\hline
\end{tabular}

Notes:

${ }^{*} \mathrm{p}<0.0$

** $p<0.01$

(1) Adj. R-Square for linear regression; Cox \& Snell R-Square for logistic regression.

spiritual leader or head clergyperson. This is again true for all religious traditions, whether they are relatively open or closed to female leadership. For example, $55.9 \%$ of members of Reformed and $40.7 \%$ of Jewish administrative boards are women, but only $24.2 \%$ of Reformed and only $6.3 \%$ of Jewish main spiritual leaders are women. In general, we found a correlation between openness at the level of administrative boards and openness at the level of head spiritual leader. An exception are Catholics, who are very open at the level of administrative boards (49.5\% women) but very closed at the level of head clergyperson ( $3.9 \%$ women). 
In Switzerland, female spiritual leadership is relatively rare. In other words, it is rare that the head pastor, rabbi, priest or spiritual guide is actually a woman. In all but three categories, we find percentages of around $10 \%$ or lower. For Evangelical-conservative and Buddhist/Hindu non-autochthonous temples, the percentage is $0 \%$. The by far highest percentages can be found in the alternative spirituality milieu, both in the groups labelled (neo-)Buddhist/Hindu alternative spirituality (42.9\%) and those categorised as other alternative spirituality (58.5\%). The female leadership found here is mostly in informal and small groups (often fewer than 15 members). A relatively high percentage of female spiritual leaders (24.2\%) can also be found in the Reformed Church.

Religious congregations typically have a parish council or board that manages the local association. This is the case for $90 \%$ of the groups in Switzerland (the 10\% without an administrative board mainly fall into the alternative spirituality category). ${ }^{6}$ We found generally high percentages of women on administrative boards, with quite a lot of variability. The lowest figures are to be found among Evangelical-conservative (19\%), Muslim (23.0\%), and Evangelical-classical (28.4\%) groups. ${ }^{7}$ The highest figures are in other alternative spirituality (63.3\%), Buddhist/Hindu alternative spirituality (60.9\%), and Reformed (55.9\%) groups. The number of women on these administrative boards is certainly an indicator of the role that women can play in the local groups. However, we should also bear in mind that these positions are normally unpaid and that leadership opportunities are often quite limited. Accordingly, it seems that, at least in some religious traditions, council positions are felt to be unattractive and difficult to fill (see Stolz and Ballif 2010 for the Reformed case).

As to the link between norms and power regarding the position of the female head clergyperson, Figure 1 shows clearly what we referred to earlier as 'loose coupling'. In the case of 'tight coupling', all the points would be on a straight and rising line. This is clearly not the case in Figure 1. Instead, there is a great deal of variability concerning norms, with some groups claiming to be closed (e.g. Orthodox, Evangelical-conservative, Roman Catholic), others more or less open (e.g. Jewish, Muslim, Other Christian, Buddhist/Hindu non-autochthonous temples, Evangelical-charismatic, Evangelical-classical), and some very open (Reformed, Buddhist/Hindu alternative spirituality). Yet, in all but three groups, the percentage of actual female leadership is about $10 \%$ or lower! To take the most salient example of 'loose coupling': almost $70 \%$ of Evangelical-charismatic groups stated that a woman could be their head pastor, but only $5.6 \%$ of Evangelical-charismatic groups actually have a female head pastor.

A multiple logistic regression predicting the gender of the spiritual leader shows that religious tradition is by far the most important predictor and explains $12.5 \%$ of the variance (Model 1). Model 2 shows that other 


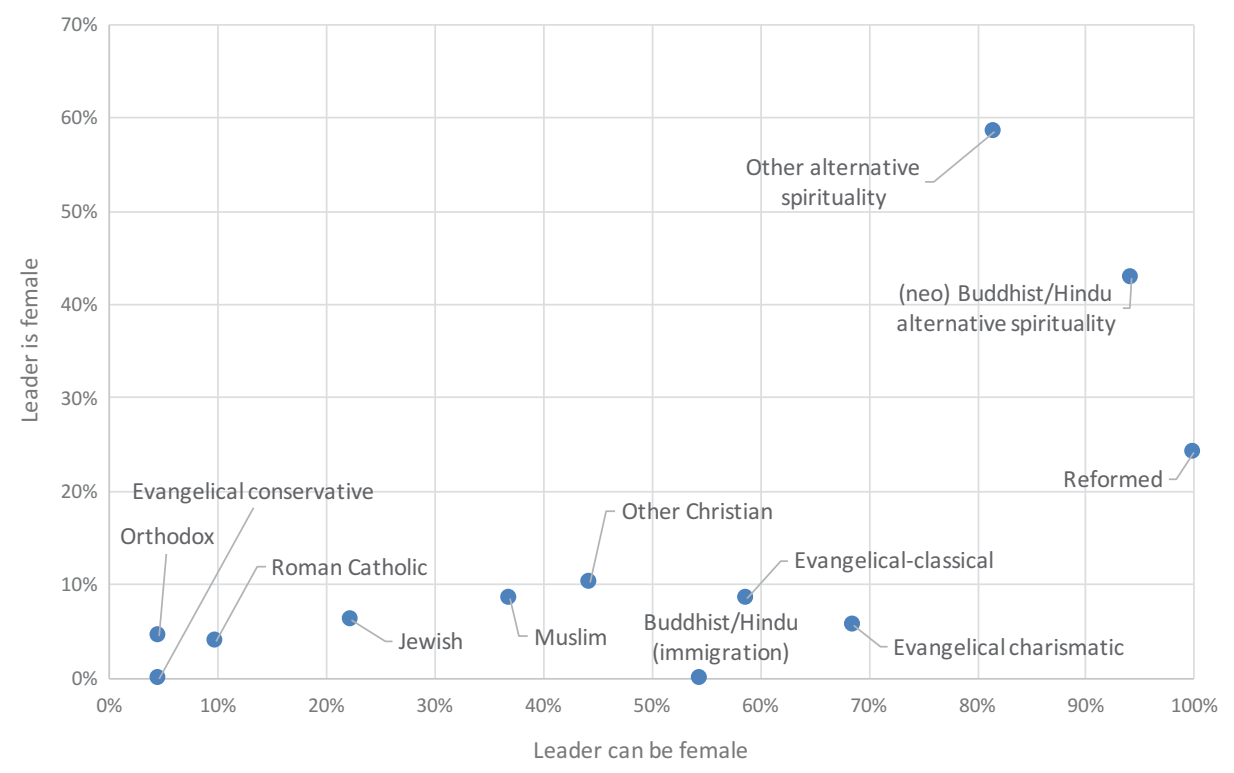

Figure 1. Possible female leadership and actual female leadership in different religious traditions.

significant predictors exist, such as theological conservatism (conservative traditions have female spiritual leaders less often), percentage of regular female members (having more female members leads to more female head clergy), and percentage of members with university education (higher level of education leads to more openness). The explained variance of Model 2 is $15.5 \%$. In Model 3, we added normative openness to the model. As we might expect, this variable has a strong and highly significant influence, but it does not raise explained variance by very much (only by $1.4 \%$ to $16.9 \%$ ). That we cannot raise explained variance further when including the predictor of normative openness shows that this predictor is correlated with other explanatory variables, such as religious tradition and theological conservatism (which no longer proves to be significant in Model 3).

\section{Money: salaried and voluntary female leadership}

Regarding the question of money and whether women are paid for their spiritual leadership in religious congregations, because of data limitations, it makes no sense to set up a multiple regression to explain paid $v s$. unpaid spiritual work. Instead, we simply compare different religious traditions according to whether or not they pay female spiritual leaders.

As Figure 2 shows, we may distinguish four different types of religious traditions with respect to our question. The first type has only very few female spiritual leaders and they are are normally volunteers (not paid). This 


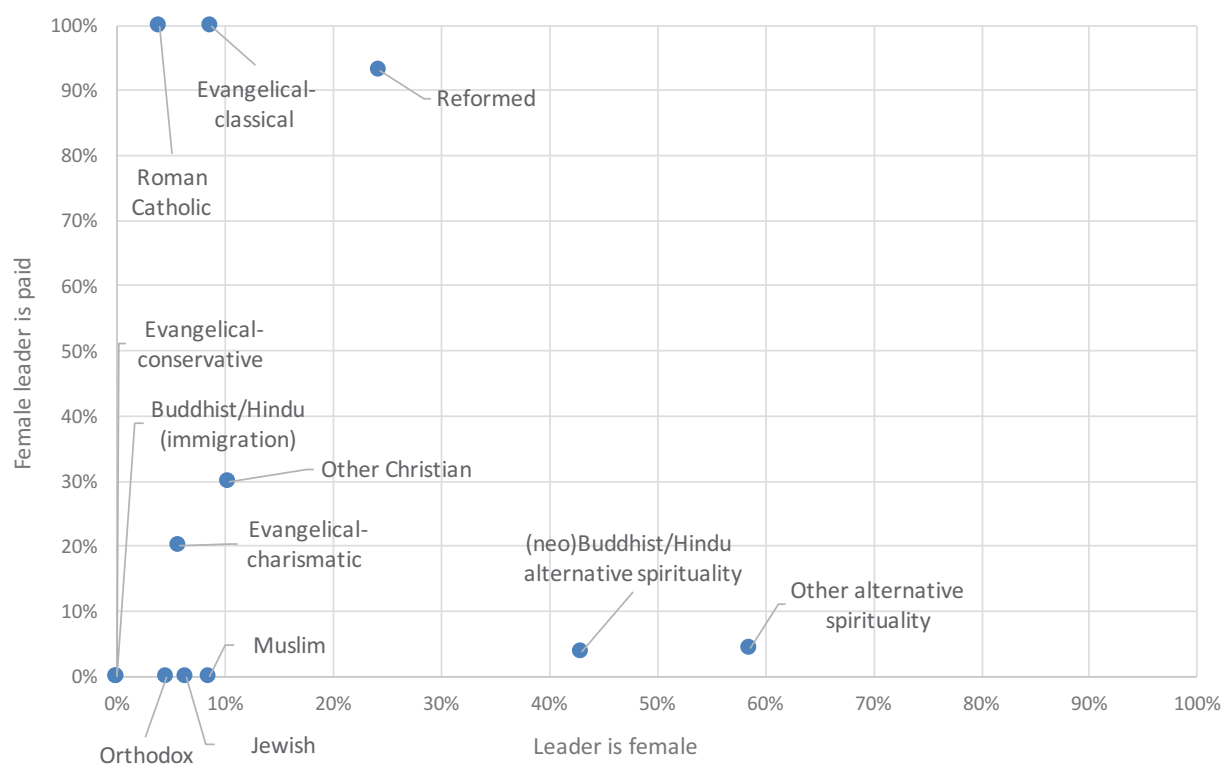

Figure 2. Percentage of spiritual leaders who are paid for their work, according to gender and religious tradition.

group includes Buddhist/Hindu non-autochthonous temples, Jewish, Muslim, Evangelical-charismatic, Evangelical-conservative, and Other Christian. The second type of religious tradition has many female spiritual leaders, but these leaders are almost all volunteers. This is the case for female spiritual leaders in the alternative spirituality milieu. Examples are women who lead Buddhist meditation or Yoga groups. The third type includes Roman Catholics and Evangelical-classical congregations. Here, there is a very low percentage of female spiritual leaders (pastoral assistants in Catholicism and female pastors for Evangelicals), but, if they are employed, they are actually paid a salary. The fourth type is represented only by Reformed congregations. This is the only religious tradition where there is a sizable percentage of women pastors (24.2\%) and where more than $90 \%$ of these female spiritual leaders are paid.

L. Ron Hubbard, the founder of the Church of Scientology, once famously stated that, in order to get rich, one should start a religion. Whatever truth there may be to this, one practical result of our research is that a woman who wants to make money (or at least to earn a salary) by becoming a spiritual leader in Switzerland and who has not yet settled on her religious identity, would be well-advised to join the Reformed Church.

\section{Conclusion}

In this article, we have compared the norms that regulate women's access to leadership positions, actual female leadership in congregations, and financial 
remuneration in such positions across the whole range of religious traditions in Switzerland. Concerning access norms, we found that high-status positions and those involving spiritual leadership are more closed to women than low-status and administrative positions. Almost all religious traditions are quite open and liberal in allowing women to teach classes or participate in governing bodies, but much more restrictive when women wish to preach at the main worship service or act as head clergy. While public discourse often singles out Muslims as having particularly closed gender norms, we found that other groups are just as or even more restrictive, such as conservative Evangelicals or Orthodox Christians.

In terms of power and women actually occupying leadership positions, we have shown that female spiritual leadership is relatively rare in Switzerland. The head pastor, rabbi, priest, guru or spiritual guide is only very seldom a woman. In all but three categories, we found percentages around or below $10 \%$. For conservative Evangelicals and Buddhist/Hindu non-autochthonous temples, the number is $0 \%$. The highest percentage of female spiritual leaders can be found in the alternative spirituality milieu, the second highest in Reformed congregations. However, we found quite high percentages of women on the administrative boards of many religious traditions.

Regarding money, we have shown that only leadership positions in certain Christian traditions-Reformed, Catholic, Evangelical-classical-normally allow women to earn money for their work in the church. This is because female leadership in many other traditions either does not exist or, as in the case of the alternative spirituality milieu, is not paid.

By far the most important factor determining access norms, power, and financial remuneration is religious tradition. It is the religious traditions and ideologies that regulate through their rules and theological legitimations the way that women can or cannot access leadership positions of varying level and financial remuneration.

Another very important determinant is the progressive-conservative dimension. Congregations that label themselves as both theologically and politically conservative are on average significantly more closed to female leadership than congregations that see themselves as more progressive. This is true even when we controlled for religious tradition. There is an issue of causality here: it may be that more conservative groups are prone to closing their leadership positions to women or that their positions on women lead them to seeing themselves as more or less conservative. However this may be, there is no doubt that the position on female leadership is one of the most salient markers of the progressive-conservative divide in religious traditions across the religious spectrum.

Furthermore, we can see that the social composition and other attributes of a congregation have some significant, although substantively rather small, effects on both norms and power. Congregations with higher percentages of younger and more educated people-and poorer people-are more likely to 
be open to female leadership. Also, congregations that have been founded more recently have access norms that are slightly more open. Congregations with higher percentages of women and members with a university education are also slightly more likely to be led by a female spiritual leader.

Our article obviously has limitations. The data used are only cross-sectional and do not show how female leadership is evolving. There is also a concern about the lack of analytical differentiation among non-Christian religions, which is mainly due to the small number of such groups. However, our findings confirm that there are indeed important barriers-what has been called a 'stained-glass ceiling' - for women who seek positions of leadership in religious congregations (Purvis 1995; Sullins 2000; Malogne-Fer and Fer 2015). What we have added to the literature is evidence that there is not just one 'stained-glass ceiling' for women in all religious traditions, but that the barriers are very variable depending on religious tradition and the progressive-conservative divide. This mapping of the territory may be used by others to add further in-depth longitudinal or explanatory studies on female leadership in specific religious congregations.

\section{Notes}

1. For a justification and discussion of the definition, see Monnot and Stolz (2014, 77-78; 2018).

2. The first female rabbi in Switzerland was Bea Wyler, who has worked in the conservative tradition since 2004 .

3. We are well aware that the alternative spiritual milieu is not just an ensemble of groups, but involves networks, publishing activities, alternative spiritual entrepreneurs that offer courses, and esoteric fairs. However, since our perspective relates to local religious groups or congregations, we only focus on groups here.

4. The number of the SNF-funded project is 4058-115719. The data can be obtained from Association of Religion Data Archives (ARDA, see http://www.thearda.com/ Archive/Files/Descriptions/NCSSWISS.asp).

5. The US and Swiss NCS used different sampling strategies. See Monnot (2013, 244-255) for more sampling details.

6. In established churches (Reformed and Catholic), the parish council is the spiritual leader's legal employer (Monnot 2013, 120-121).

7. With important discrepancies between Evangelical-classical denominations; see Monnot $(2015,228)$.

\section{Acknowledgments}

We would like to express our thanks to Martin Baumann, Andreas Tunger-Zanetti, Christine Rodier, and Kati Niemelä for help with the literature review and the interpretation of some results. We are grateful to the two anonymous reviewers of the Journal of Contemporary Religion for very helpful feedback. We would also like to thank David West for correcting the text. 


\section{Disclosure statement}

No potential conflict of interest was reported by the authors.

\section{Notes on contributors}

Jörg Stolz is professor of sociology of religion at the University of Lausanne, Switzerland. $\mathrm{He}$ combines a theoretical interest with both quantitative and qualitative empirical research. Theoretically, he works on a general theory of social games and a theory of religious-secular competition. He has conducted research on evangelicalism, the explanation of secularisation and resacralisation, comparative research on congregations in different religions, and secular and atheist beliefs. He is currently the president of the International Society for the Sociology of Religion (ISSR).

Christophe Monnot is assistant professor of sociology of religion at the University of Strasbourg, France, and senior researcher at the University of Lausanne, Switzerland. His work focuses on religious institutions and congregations. He has worked on several grants to pursue his research on the implantation and institutionalisation process of mosques in France and Switzerland. He is the author of a number of articles and (co-)editor of books in French and English, including Congregations in Europe (2018). He has been on the committee of Research Network 34 (Sociology of Religion) of the European Sociological Association (ESA) since 2011.

CORRESPONDENCE: Jörg Stolz, ISSR, University of Lausanne, 1015 Lausanne, Switzerland.

\section{References}

Adams, Jimi. 2007. "Stained Glass Makes the Ceiling Visible: Organizational Opposition to Women in Congregational Leadership." Gender \& Society 21 (1): 80-105.

Baumann, Martin. 2007. "Götter, Gurus, Geist und Seele: Hindu-Traditionen in der Schweiz." In Eine Schweiz-viele Religionen: Risiken und Chancen des Zusammenlebens, edited by Martin Baumann and Jörg Stolz, 223-237. Bielefeld: transcript.

Cadge, Wendy. 2004. "Gendered Religious Organizations: The Case of Theravada Buddhism in America." Gender \& Society 18 (6): 777-793.

Chaves, Mark. 1997. Ordaining Women: Culture and Conflict in Religious Organizations. Cambridge, MA: Harvard University Press.

Chaves, Mark. 2004. Congregations in America. Cambridge, MA: Harvard University Press.

Davie, Grace. 1994. “The Religiosity of Women Understanding Paradox." Conference paper, University of Lausanne, 1-3 December.

de Gasquet, Béatrice. 2009. "La barrière et le plafond de vitrail: Analyser les carrières féminines dans les organisations religieuses." Sociologie du Travail 51 (2): 218-236.

Ebaugh, Helen Rose, and Janet Saltzman Chafetz. 1999. "Agents for Cultural Reproduction and Structural Change: The Ironic Role of Women in Immigrant Religious Institutions." Social Forces 78 (2): 585-612.

Flaugergues, Amélie de. 2016. Pratiques et croyances religieuses et spirituelles en Suisse: premiers résultats de l'enquête sur la langue, la religion et la culture 2014. Neuchâtel: Office fédéral de la statistique (OFS). 
Gill, Deborah M., and Ava K. Oleson. 2013. "Pentecostal Female Pastors." In Religious Leadership: A Reference Handbook, edited by Sharon Henderson Callahan, 282-286. Thousand Oaks, CA: Sage.

Heelas, Paul, and Linda Woodhead, with Benjamin Seel, Bronislaw Szerszynski, and Karin Tusting. 2005. The Spiritual Revolution: Why Religion is Giving Way to Spirituality. Oxford: Blackwell.

Höllinger, Franz, and Thomas Tripold. 2012. Ganzheitliches Leben: Das holistische Milieu zwischen neuer Spiritualität und postmoderner Wellness-Kultur. Bielefeld: transcript.

Houtman, Dick, and Stef Aupers. 2006. "The Spiritual Revolution and the New Age Gender Puzzle: The Sacralisation of the Self in Late Modernity, 1980-2000." In Women and Religion in the West: Challenging Secularization, edited by Giselle Vincett, Sonia Sharma, and Kristin Aune, 99-118. Aldershot: Ashgate.

Konieczny, Mary Ellen, and Mark Chaves. 2000. "Resources, Race, and Female-headed Congregations in the United States." Journal for the Scientific Study of Religion 39 (3): 261-271.

Kunz, Ralph, and Rebecca Giselbrecht-Häfner. 2014. "Zu viel Verstand-zu wenig Herz." Facultativ: Magazinbeilage zur Reformierten Presse 2: 6.

Malogne-Fer, Gwendoline, and Yannick Fer, eds. 2015. Femmes et pentecôtismes: enjeux d'autorité et rapports de genre. Geneva: Labor et Fides.

Marx, Dalia. 2013. "A Female Rabbi is like an Orange on the Passover Plate: Women and the Rabbinate-Challenges and Horizons." In Rabbi-Pastor-Priest, edited by Walter Homolka and Heinz-Günther Schöttler, 219-240. Berlin: De Gruyter.

Min, Pyong Gap. 2008. "Severe Underrepresentation of Women in Church Leadership in the Korean Immigrant Community in the United States." Journal for the Scientific Study of Religion 47 (2): 225-241.

Monnot, Christophe. 2013. Croire ensemble: analyse institutionnelle du paysage religieux en Suisse, terrains des sciences sociales. Zurich: Seismo.

Monnot, Christophe. 2015. "Pouvoir et genre en pentecôtisme: d'un 'paradoxe' à l'autre. Analyse à partir d'une enquête quantitative suisse." In Femmes et pentecôtismes: enjeux d'autorité et rapports de genre, edited by Gwendoline Malogne-Fer and Yannick Fer, 217-242. Geneva: Labor et Fides.

Monnot, Christophe, and Jörg Stolz. 2014. "The Diversity of Religious Diversity: Using Census and NCS Methodology in Order to Map and Assess the Religious Diversity of a Whole Country." In Religious Pluralism: Framing Religious Diversity in the Contemporary World, edited by Giuseppe Giordan and Enzo Pace, 73-91. Cham: Springer.

Monnot, Christophe, and Jörg Stolz. 2018. "How do you Recognize a 'Congregation'? Defnition and Operationalization Strategies of the Swiss Congregation Census." In Congregations in Europe, edited by Christophe Monnot and Jörg Stolz, 15-32. Cham: Springer.

Niemelä, Kati. 2011. “Female Clergy as Agents of Religious Change?” Religions 2 (3): 358-371.

Pahud de Mortanges, René. 2007. "System und Entwicklungstendenzen des Religionsverfassungsrechts der Schweiz und des Fürstentums Liechtenstein.” Zeitschrift für Evangelisches Kirchenrecht 52 (3): 495-523.

Purvis, Sally B. 1995. The Stained Glasses Ceiling: Churches and their Women Pastors. Louisville, KY: Westminster John Knox Press.

Rageth, Nina. 2014. "Priesterinnen im Hinduismus." Facultativ: Magazinbeilage zur Reformierten Presse 2: 12.

Riesebrodt, Martin, and Kelly H. Chong. 1999. "Fundamentalisms and Patriarchal Gender Politics.” Journal of Women's History 10 (4): 55-77. 
Sharify-Funk, Meena, and Munira Kassam Haddad. 2012. "Where Do Women 'Stand' in Islam? Negotiating Contemporary Muslim Prayer Leadership in North America." Feminist Review 102 (1): 41-61.

Stolz, Jörg, and Edmée Ballif. 2010. Die Zukunft der Reformierten: Megatrends-Wirkungen -Reaktionen. Zürich: TVZ.

Stolz, Jörg, and Mark Chaves. 2017. "Does Disestablishment Lead to Religious Vitality? The Case of Switzerland.” British Journal of Sociology 69 (2): 1-24.

Stolz, Jörg, Mark Chaves, Christophe Monnot, and Laurent Amiotte-Suchet. 2011. Die religiösen Gemeinschaften in der Schweiz: Eigenschaften, Aktivitäten, Entwicklung. Berne: Fonds national suisse (FNS).

Stolz, Jörg, Judith Könemann, Mallory Schneuwly Purdie, Thomas Englberger, and Michael Krüggeler, eds. 2016. (Un)Believing in Modern Society: Religion, Spirituality, and Religious-Secular Competition. Farnham, Surrey: Ashgate.

Sullins, Paul. 2000. "The Stained Glass Ceiling: Career Attainment for Women Clergy.” Sociology of Religion 61 (3): 243-266.

Voas, David, Siobhan McAndrew, and Ingrid Storm. 2013. "Modernization and the Gender Gap in Religiosity: Evidence from Cross-national European Surveys.” Kölner Zeitschrift für Soziologie und Sozialpsychologie 65 (1, Supplement): 259-283.

Walter, Tony, and Grace Davie. 1998. "The Religiosity of Women in the Modern West." British Journal of Sociology 49 (4): 640-660.

Wessinger, Catherine. 1993. Women's Leadership in Marginal Religions: Explorations Outside the Mainstream. Urbana, IL: University of Illinois Press.

Willaime, Jean-Paul. 1996. "L'accès des femmes au pastorat et la sécularisation du rôle du clerc dans le protestantisme." Archives de sciences sociales des religions 95 (juillet-septembre): 29-45. Woodhead, Linda. 2008. “Gendering Secularization Theory.” Social Compass 55 (187): 187-193. 